\title{
BEYOND PARLIAMENTARY SOVEREIGNTY AND JUDICIAL SUPREMACY: THE DOCTRINE OF IMPLICIT LIMITS TO CONSTITUTIONAL REFORM IN LATIN AMERICA
}

\author{
Joel Colón-Ríos*
}

\begin{abstract}
This article provides an introduction to the Latin American doctrine of implicit limits to constitutional reform. The article begins by discussing the way in which this doctrine relates to (and differs from) the doctrine of the basic structure, adopted in several common law jurisdictions such as India and Belize. It then examines a decision of the Constitutional Court of Colombia in which the doctrine of implicit limits received one of its clearest formulations. Finally, it is argued that the Latin American approach goes beyond both parliamentary sovereignty and judicial supremacy, providing the constituent people (as opposed to Parliament and the courts) with the final word on the validity of important constitutional changes.
\end{abstract}

\section{INTRODUCTION}

The doctrine of implicit limits to the power of constitutional reform has been the subject of recent discussions by constitutional theorists. ${ }^{1}$ Briefly put, the idea is that even in the absence of unamendable constitutional clauses, there are certain constitutional changes that are out of the scope of the amending power. The power of constitutional reform, it is said, can be used to alter the constitutional text in numerous ways, but not in ways that contradict the fundamental principles on

* Senior Lecturer, Faculty of Law, Victoria University of Wellington.

1 See for example Carlos Bernal, "Unconstitutional Constitutional Amendments in the Case Study of Colombia: An Analysis of the Justification and Meaning of the Constitutional Replacement Doctrine" (2013) 11 ICON 339; Rosalind Dixon "Transnational Constitutionalism and Unconstitutional Constitutional Amendments" (Chicago Public and Legal Theory Working Paper No 349, May 2011); Richard Albert "Nonconstitutional Amendments" (2009) 22 CJLJ 5; Gary Jeffrey Jacobsohn Constitutional Identity (Harvard University Press, Cambridge (Mass), 2010); Walter Murphy Constitutional Democracy: Creating and Maintaining a Just Political Order (The John Hopkins University Press, Baltimore, 2008). 
which the constitution is based. Constitutional amendments that are 'unconstitutional' are invalid, and can be thus struck down by judges. This doctrine, of course, belongs to the terrain of written and supreme constitutions, legal systems in which judges routinely invalidate decisions made by the elected branches of government. Accordingly, different versions of the doctrine have been influential in countries with supreme constitutions and very active courts (and legislatures that frequently adopt constitutional amendments), such as India and Colombia.

One may nevertheless argue that the basic premises of common law constitutionalism, as defended by some in the context of countries with unwritten constitutions, are not that different. After all, common law constitutionalism assigns courts the role of protecting certain fundamental principles (identified and defined by courts) from the decisions of Parliament. ${ }^{2}$ These principles are taken to be the basis of a 'common law constitution', and judges have the power to enforce them against the decisions of Parliament. ${ }^{3}$ There are various academic and judicial defences (and critiques) of common law constitutionalism. ${ }^{4}$ As usefully put by Tom Mullen, these views all point towards the idea that "that there may be substantive limitations on the competence of Parliament to legislate inherent in the common law, such that courts might have the power to declare invalid legislation inconsistent with fundamental rights or fundamental values such as democracy and the rule of law". 5 The strongest judicial (obiter) comments in favour of this approach are the ones made by some of the Lords in Jackson $v$ Attorney General. ${ }^{6}$

For example, Lord Steyn suggested that: ${ }^{7}$

... in exceptional circumstances involving an attempt to abolish judicial review or the ordinary role of the courts, [the Supreme Court] may have to consider whether this is a constitutional fundamental which even a sovereign Parliament [cannot abolish].

2 Thomas Poole "Back to the Future? Unearthing the Theory of Common Law Constitutionalism" (2003) 23 OJLS 435 at 439 .

3 For a discussion see Jeffrey Goldsworthy Parliamentary Sovereignty: Contemporary Debates (Cambridge University Press, Cambridge, 2010) at 14-18.

4 See for example John Laws, "Law and Democracy" (1995) PL 72; Trevor Allan Constitutional Justice: A Liberal Theory of the Rule of Law (Oxford University Press, Oxford, 2001); Lord Cooke of Thorndon "The Myth of Sovereignty"" (2005) 3 NZJPIL 39;"The Myth of Sovereignty" (see also Lord Cooke's judgment in Taylor v New Zealand Poultry Board [1984] 1 NZLR 394 (CA) at 398 per Cooke J).

5 Tom Mullen "Reflections on Jackson v. Attorney General: Questioning Sovereignty" 27 JLS 1 at 13.

6 Per Lord Steyn, Lord Hope, and Baroness Hale.

7 Jackson v Attorney General [2005] UKHL 56 at [102]. Lord Steyn made these obiter comments in the context of a discussion of legislation adopted by the House of Commons and the Crown under the provisions of the Parliament Act 1949, but his comments here appear to be of a more general character. 
Baroness Hale maintained that courts will "treat with suspicion (and might even reject) any attempt to subvert the rule of law by removing governmental action affecting the rights of the individual from all judicial scrutiny". ${ }^{8}$ Similarly, but this time writing extra-judicially, Lord Hope has stated that the absence of a general power to strike down legislation: ${ }^{9}$

...does not mean that the courts could never fashion a remedy for use in an exceptional case where the survival of the rule of law itself was threatened because their role as the ultimate guardians of it was

being removed from them.

If ever accepted in actual constitutional practice, this doctrine would invert the relationship between Parliament and the courts; it would put an end to the sovereignty of Parliament and embrace what could be fairly described as a system of judicial supremacy.

Although occurring in a context in which there is no clear distinction between the ordinary lawmaking power and the power of constitutional reform, common law constitutionalism would impose limits on Parliament's ability to change the unwritten constitution (as laws that somehow touch on fundamental common law principles would normally have constitutional significance). In that respect, both common law constitutionalism and the doctrine of implicit limits to constitutional reform would provide judges the right to identify unwritten principles that act as limits to the constitution-amending power of an elected legislature. ${ }^{10}$ As a result, one may say that a convergence between the doctrine of implicit limits (as developed in countries with supreme constitutions) and common law constitutionalism (as developed in countries with unwritten constitutions) is taking place. This statement might be accurate with respect to the versions of the doctrine of implicit limits adopted in some common law countries such as India and Belize, but not with respect to the way in which the doctrine has developed in Latin America.

What makes the Latin American version of the doctrine different is that it is ultimately based on the theory of the people's constituent power. Consequently, it gives judges the power to strike down 'unconstitutional' constitutional amendments that offend certain principles, ${ }^{11}$ but only to protect the

8 At [159].

9 Lord Hope of Craighead "A View from the Bench" (paper presented at the WG Hart Legal Workshop Sovereignty in Question, London, June 2011).

10 In one of its best-known decisions, the Canadian Supreme Court elaborated on "four fundamental and organizing principles of the Constitution" (namely federalism, democracy, constitutionalism and the rule of law, and respect for minorities): Reference re Secession of Quebec [1998] 2 SCR 217 at [32]. It is certainly possible (even if unlikely given the infrequency of constitutional amendments in Canada and taking into account that country's political culture) that, faced with a constitutional amendment inconsistent with one of those principles, the Supreme Court may adopt the doctrine of implicit limits to constitutional reform and invalidate the amendment in question.

11 As will be noted from the discussion below, the principles identified by proponents of common law constitutionalism and by courts adopting some version of the doctrine of implicit limits to constitutional reform share some important similarities. 
people's exclusive constitution-making power, which may be exercised at any moment and prevail over any judicial decision. As will be seen, while the final institutional implication of common law constitutionalism is a very strong form of judicial review of legislation (a system in which judges have the final word on the validity of constitutionally significant laws that offend certain unwritten principles without those decisions being vulnerable to subsequent constitutional amendments), the Latin American approach results in a system in which the people are invited to exercise their constituent power to challenge judicially defined limits on constitutional change.

This article provides an introduction to the Latin American doctrine of implicit limits to constitutional change, and distinguishes it from other approaches that seek to limit Parliament's power of constitutional reform. Section II discusses the way in which this doctrine relates (and differs) from the doctrine of the basic structure, adopted in several common law jurisdictions, such as India and Belize. Section III examines a decision of the Constitutional Court of Colombia in which the doctrine of implicit limits to constitutional reform received one of its major developments. Finally, the article argues that the Latin American approach goes beyond both parliamentary sovereignty and judicial supremacy, providing the constituent people (as opposed to Parliament or to the courts) with the final word on the validity of important constitutional changes.

\section{ETERNITY CLAUSES AND THE BASIC STRUCTURE DOCTRINE}

The idea that the content of constitutional amendments may be limited by law is not new. Some 19th century constitutions, in fact, attempted to make certain principles or institutions unchangeable. The Constitution of Ohio (1803), for example, stated in its amendment rule that "[N]o alteration of this constitution shall ever take place, so as to introduce slavery or involuntary servitude into this State". ${ }^{12}$ Nowadays that sort of provision is much more common, and it is usually referred to by the name of 'eternity clause'. For example, art 60 of Brazil's Constitution (1988) prohibits amendments that abolish federalism, universal suffrage, the separation of powers, and individual rights; art 139 of the Constitution of Italy (1947) establishes that "The republican form of the state may not be changed by way of constitutional amendment"; and art 79.3 of the German Basic Law (1949) states that:

Amendments to this Basic Law affecting the division of the Federation into Länder, their participation

on principle in the legislative process, or the principles laid down in arts 1 and 20 shall be inadmissible.

12 Article VII, s 5. In the mid 17th century England, Oliver Cromwell (distinguishing between 'fundamental' and 'circumstantial' elements of government) argued that there were certain aspects of the Instrument of Government that were unalterable: "In every government there must be somewhat fundamental, somewhat like a Magna Charta, that should be standing and be unalterable". Among these 'fundamentals' he included the "the government by a single person and a parliament", and the rule "that parliaments should not make themselves perpetual." Oliver Cromwell "Speech to the first Protectorate Parliament" (12 September 1654). See J W Gough Fundamental Law in English Constitutional History (Clarendon Press, Oxford, 1955) at $129-130$. 
In making some constitutional changes legally inadmissible by placing explicit limits on the amending power, eternity clauses serve the purpose of protecting principles that are considered fundamental in a particular juridical order. Put differently, they are ways of preserving the ideological presuppositions in which a state rests. In such constitutional orders, carefully following the constitutionally mandated process of constitutional reform is not enough to produce a valid amendment: courts are not only empowered to declare an amendment invalid as a result of procedural irregularities, but also to assess their content in light of the prohibitions contained in the eternity clause. Of course, some eternity clauses are more general than others, and thus invite for more intrusive forms of judicial review. For example, art 116 the old Constitution of Nepal (1990) prohibited amendments that violated "the spirit of the Preamble". ${ }^{13}$ The interpretative power that such type of provision places in courts is such that the limits to constitutional change can hardly be described as 'explicit'. ${ }^{14}$

However not all constitutions contain eternity clauses. In order to fill that void (and thus to fulfil the function that an eternity clause would serve), some courts have developed the doctrine of implicit limits to constitutional reform. The most famous example is that of India, whose constitution does not contain any eternity clauses. In Kesavananda Bharati $v$ Kerala, ${ }^{15}$ a case that dealt with a series of land reforms that affected property rights, the Supreme Court of India determined that while Parliament had the power to amend any constitutional provision, it could not alter the basic structure of the constitution. For the court, the constitution's preamble and some constitutional clauses implicitly attributed a special importance to some principles, and in order for a constitutional amendment to be valid, it needed to be consistent with them (among the principles mentioned in the different concurring opinions where those of constitutional supremacy, the republican form of government, federalism, the welfare state, individual liberty, and secularism). ${ }^{16}$

The basic structure doctrine, in a way, abolishes the last remnant of parliamentary sovereignty in systems that have adopted a written and supreme constitution: it prevents a special parliamentary

13 For a discussion of the Nepalese case, see Richard Stith "Unconstitutional Constitutional Amendments: The Extraordinary Power of Nepal's Supreme Court" (1996) 11 AUILR 47. Article 112 of the Constitution of Norway (1814) contains a similar provision which establishes that amendments "must never ... contradict the principles embodied in this Constitution, but solely relate to modifications of particular provisions which do not alter the spirit of the Constitution". It is not clear whether this limit is judicially enforceable. See Eivind Smith "Old and Protected? On the 'Supra-Constitutional' Clause in the Constitution of Norway" (2011) 44 ISR 369 at 385.

14 In fact even more specific eternity clauses, like that of art 79 of the Basic Law, still require judges to give content to concepts as broad as 'human dignity'. See for example the judicial discussions in The Klass Case (1970) 30 BVerGE 1 and The Electronic Eavesdropping Case (2003) 109 BverfGE 279.

15 Kesavananda Bharti Sripadagalvaru v State of Kerala (1973) SCR 0001 (Supreme Court of India).

16 For a discussion, see Rory O'Connell "Guardians of the Constitution: Unconstitutional Constitutional Norms" (1999) 4 J Civil Liberties 69. 
majority from amending the constitution in order to render ineffective a judicial invalidation of an ordinary law. The doctrine was developed further in Minerva Mills $v$ Union of India, ${ }^{17}$ where the Supreme Court expressed that the amending power could not be used to destroy the "identity" of the existing constitution. ${ }^{18}$ Accordingly, it struck down an amendment through which Parliament attempted to attribute itself with an unlimited amending power (therefore preventing the future applicability of the basic structure doctrine).${ }^{19} \mathrm{~A}$ decade later, the Constitutional Court of South Africa had the opportunity to consider the applicability of the basic structure doctrine in that country's legal order.

In Premier of Kwazuly Natal v President of South Africa, ${ }^{20}$ the claimants asked the Court to invalidate a number of amendments to the Interim Constitution (among other things, the amendments increased the powers of the President with respect to provincial and local governments), and invited the Court to adopt doctrine of the basic structure. The Court upheld the validity of the amendments in question, but timidly asserted its jurisdiction to review the content of constitutional amendments if they violated certain implicit limits. "Even if there is this kind of implied limitation to what can properly be the subject matter of an amendment to our Constitution", expressed the court, "[neither of these amendments] can conceivably fall within this category of amendments so basic to the Constitution as effectively to abrogate or destroy it". ${ }^{21}$ In contrast, the Supreme Court of Belize, in a series of recent decisions, has adopted and applied the doctrine of the basic structure, openly relying on Indian jurisprudence.

17 Minerva Mills v Union of India [1980] AIR 1789; [1981] 1 SCR 206 (Supreme Court of India).

18 At 286.

19 The relevant part of the amendment reads as follows:

For the removal of doubts, it is hereby declared that there shall be no limitation whatever on the constituent power of Parliament to amend by way of addition, variation or repeal the provisions of this Constitution under this article.

For a recent book-length examination of the doctrine of the basic structure, see Sudhir Krishnaswamy Democracy and Constitutionalism in India: A Study of the Basic Structure Doctrine (Oxford University Press, India, 2009).

20 Premier of Kwazuly Natal v President of South Africa [1995] CCT 36/95 (Constitutional Court).

21 At [49]. Whether these expressions are still valid under the 1996 Constitution is an open question, given that that s 74 of that Constitution establishes that s 1 of the constitution (which protects principles as fundamental as human dignity, the achievement of equality and the advancement of human rights and freedoms, non-racialism and non-sexism, the supremacy of the constitution and the rule of law) can be amended by a bill passed by

(a) the National Assembly, with a supporting vote of at least 75 per cent of its members; and (b) the National Council of Provinces, with a supporting vote of at least six provinces. 
The first of these decisions is Bowen v Attorney General. ${ }^{22}$ In that case, the Court invalidated the Sixth Amendment, which had the effect of excluding certain natural resources (including petroleum) from the protections of the right to property. The Court expressed that the amendment, by impeding access to the courts to challenge alleged infringements of property rights, offended: ${ }^{23}$

the basic structure of the Constitution of Belize regarding the principle of the separation of powers and...the rule of law and the protections of fundamental rights especially those relating to the ownership and protection of property from arbitrary deprivation.

More recently, in 2012, the Supreme Court of Belize struck down part of the Eighth Amendment, which (as the amendment invalidated by the Supreme Court of India in Minerva Mills) declared that the amending power of the National Assembly was not subject to any other limitations ("substantive or procedural") than those contained in the constitution's amendment rule. ${ }^{24}$

Attributing a special role to the constitution's preamble ("the root of the tree from which the provisions of the Constitution spring"), ${ }^{25}$ the Court expressed that: ${ }^{26}$

... the basic structure doctrine holds that the fundamental principles of the Preamble of the Constitution

have to be preserved for all times to come and that they cannot be amended out of existence.

The Court continued: ${ }^{27}$

The framers of the Preamble could not have intended that the National Assembly with the required majorities ... could make literally any amendment to the Constitution to, for instance, abolish the judiciary, or expropriate private property without compensation, or imprison its enemies without trial.

22 Barry M Bowen v Attorney General of Belize (2008]) Claim No 445 (Supreme Court of Belize).

23 See also The Prime Minister of Belize v Alberto Vellos [2010] UKPC 7.

24 The Eighth Amendment also stated that

the Government shall have and maintain at all times majority ownership and control of a public utility provider; and any alienation of the Government shareholding or other rights, whether voluntary or involuntary, which may derogate from Government's majority ownership and control of a public utility provider shall be wholly void and of no effect notwithstanding anything in section 20 or any other provision of this Constitution or any other law or rule practice...

The second part of that declaration (as well as other parts of the amendment affecting property rights and access to courts) was struck down by the court on the basis of the basic structure doctrine, under a reasoning similar to that of Bowen.

25 The British Caribbean Bank Limited v Attorney General of Belize (2011) Claim No 597 (Supreme Court of Belize) at [50].

26 At [45].

27 At [45] 
As noted in the introduction with respect to common law constitutionalism, one of the implications of the Indian doctrine of the basic structure is that judges, and not Parliament, are given the final word on the validity of fundamental constitutional changes. ${ }^{28}$

Even though they occur in different constitutional systems, the former in systems with unwritten and flexible constitutions, the latter in systems with written and supreme fundamental laws, both common law constitutionalism and the doctrine of the basic structure assume that the limits on constitutional change are absolute limits, that is, limits that no legally relevant entity can surpass (as a matter of fact, not of law, any of these limits could of course be surpassed by a revolution). In other words, if the ultimate power to determine which constitutional amendments are to be considered valid law is taken away from parliament, then the only option is for this power to be held by courts. In Latin America, however, the doctrine has taken a different form: the limits on constitutional change are thought to apply to the ordinary institutions of government (Parliament and courts) but not to the people in the exercise of their constituent power. ${ }^{29}$ After briefly outlining the theory of constituent power, the next section considers the Latin American version of this doctrine, focusing in a landmark 2003 decision from the Colombian Constitutional Court.

\section{CONSTITUENT POWER AND CONSTITUTIONAL REFORM: THE LATIN AMERICAN APPROACH}

The Colombian Constitutional Court adopted the doctrine of implicit limits to constitutional reform in 2003, but on somewhat different grounds than those used to justify the doctrine in common law countries like India and Belize. ${ }^{30}$ The Court decided that although the Colombian Constitution did not contain eternity clauses, the amending power could not be used adopt constitutional changes so fundamental that amounted to the creation of a new constitution. The Court reached this conclusion through an application of the theory of constituent power, which I outline below. Emmanuel Sieyes first developed the theory of constituent power during the French Revolution. ${ }^{31}$ Sieyes advanced a distinction between constituent power and the constituted powers: the former was to be understood as an unlimited power to create new constitutions (which was

28 Other countries in which the Indian doctrine of the basic structure has been influential include Bangladesh and Sri Lanka. For a brief discussion, see Gábor Halmai "Unconstitutional Constitutional Amendments: Constitutional Courts as Guardians of the Constitution?" (2012) 19 Constellations 182.

29 It could be argued that the doctrine of the basic structure (and possibly common law constitutionalism), is consistent with the idea that the people (as opposed to Parliament), always retains an unlimited (constituent) power to make any constitutional changes. However, as will be seen in Section IV, what characterises the Latin American approach is that it provides 'the people' with specific mechanisms to exercise that power.

30 Sentencia 551/03 Colombian Constitutional Court, 9 July 2003.

31 Emmanuel Sieyes What is the Third Estate? (Praeger, New York, 1963). For a contemporary discussion of the theory of constituent power and its implications for contemporary constitutional theory, see Joel I Colón-Ríos Weak Constitutionalism: Democratic Legitimacy and the Question of Constituent Power (Routledge, Oxford, 2012). 
always retained by the people, or in Sieyes terminology, by 'the nation'); the latter referred to ordinary governmental institutions, whose power is always limited and regulated by the constitution.

Sieyes' theory was further developed by Carl Schmitt, the controversial German jurist, who defined constituent power as "the political will, whose power or authority is capable of making the concrete, comprehensive decision over the type and form of political existence". ${ }^{32}$ These fundamental political decisions generally refer to the basic structure of the state (whether it takes the form of a republic or a monarchy, of a unitary or a federal system, of a liberal democracy or a socialist order). ${ }^{33}$ Schmitt did not think that the constituent power vanishes or is forever channeled through the constitutional amendment procedure after these decisions are in place. On the contrary, he maintained that even after being exercised, constituent power, as a legally unlimited power, continued to exist "alongside and above the constitution". ${ }^{34}$ The theory of constituent power, in its Schmittian version, has long been present in Latin American constitutional theory and practice, and it played an important role in the Colombian case discussed below. ${ }^{35}$

In 2003, the Colombian Constitutional Court was asked to review the substance of a set of proposed constitutional changes that were supposed to come into existence after their approval in a referendum. The amendments dealt with a number of controversial issues, such as the modification of the electoral system, the alteration of the budget process, the regulation of political parties, the public policy on drug related offences, and the prolongation of the period in office of the governors and mayors. Supporters of the amendments argued that in assessing their constitutionality, the Court had to limit itself to examine whether the formal requirements established in the constitution's amendment rule were met. They based that argument on the text of art 241 of the Colombian Constitution, which clearly stated that the Court could invalidate a constitutional amendment 'only for procedural or formal defects'. The claimants, on the contrary, argued that a constitutional amendment could be declared unconstitutional by the Court if it contradicted the fundamental principles in which the constitution rested.

Not surprisingly, an important part of the decision focused on the meaning of the phrase 'only for procedural or formal defects'. The Court expressed that its role with respect to a proposed constitutional amendment was, just as art 241 stated, ensuring that the procedural requirements of the amendment process were strictly followed. In other words, unlike in the exercise of judicial

32 Carl Schmitt Constitutional Theory (Duke University Press, Durham, 2007) at 125.

33 At $77-78$.

34 At $125-126$

35 This discussion of Sentencia 551/03 of the Colombia Constitutional Court relies heavily on Joel I ColónRíos "Carl Schmitt and Constituent Power in Latin American Courts: The Cases of Venezuela and Colombia" (2011) 18 Constellations 365. For an extended discussion of the doctrine, see Gonzalo Ramirez Cleves Límites de la Reforma Constitucional en Colombia: El Concepto de Constitución como Fundamento de la Restricción (Universidad Externado de Colombia, Bogotá, 2005). 
review of legislation, the Court did not have jurisdiction to assess whether the substance of an amendment was inconsistent to the constitutional text. However, the Court maintained that in the context of constitutional reform, procedure and substance overlapped with each other. According to the Court, competence (competencia, understood as the power of producing a determinate legal consequence) is an essential part of any procedure: it would be legally meaningless to follow each of the requirements of a particular procedure if one lacked the competence to use that procedure to produce the desired outcome. ${ }^{36}$

When art 241 of the Constitution of 1991 restricts the review power of the Court with respect to constitutional amendments to that of identifying procedural or formal defects, the Court reasoned, it is necessarily conferring that body the power to examine if the institution promoting the constitutional changes is acting ultra vires. ${ }^{37}$ Otherwise the Court would be unable to exercise its duty to protect the constitution when confronted with a constitutional change adopted with a strict adherence to the amendment rule, but by an organ without the competence to bring that kind of change into existence. Under this approach, the Court would be required to assess the content of a proposed amendment to determine if it is out of the scope of the amending power, and this would be entirely consistent with the clear mandate of art 241. However, for this argument to have any practical implications in Colombia, the court needed to show that the power of constitutional reform, under the Constitution of 1991, was somehow limited; that it was susceptible of being exercised ultra vires even in the absence of eternity clauses.

As a consequence, the Court had to set the basis for the doctrine of implicit limits to constitutional reform. The Court began by noting that legal scholars and courts around the world have recognized that under any democratic constitution (even under one that does not contain unamendable or eternity clauses) the power of constitutional reform is subject to certain substantive limits. ${ }^{38}$ These limits, the Court continued, emerge from the nature of the power of constitutional reform as a constituted, rather than a constituent, power. ${ }^{39}$ The Court defined constituent power "as a power which belongs to the people, who always retains the capacity of giving itself a Constitution". ${ }^{40}$ It characterised it as "absolute, unlimited, permanent, without limits or

36 Sentencia 551/03, above n 30, at [22]

37 At [23].

38 The court here mostly relied in the Indian jurisprudence briefly discussed in the first section of this article and also referred to the writings of several European and Latin American authors, including Karl Lowenstein Teoría de la Constitución (Ariel, Barcelona,1986); Carl Schmitt Teoría de la Constitución. (Editorial Revista de Derecho Privado, Madrid, 1934); Georges Burdeau Traité de Science Politique (LGDJ, Paris, 1969); Pedro de Vega La Reforma Constitucional y la Problemática del Poder Constituyent (Tecnos, Madrid, 1999); Germán Bidart Campos Historia e Ideología de la Constitución Argentina (Ediar, Buenos Aires, 1969)

39 Sentencia 551/03, above n 30, at [28].

40 At [29]. 
jurisdictional controls, because its acts are political and foundational and not juridical, whose validity derives from the political will of the society". ${ }^{41}$

The Court added that political communities in contemporary states remained permanently free to exercise, in an episodical and transitional manner, their constituent power "in order to revise or modify its fundamental political decisions and to give its juridical institutions, new forms and content...". ${ }^{42}$ The fact that the Constitution of 1991 did not contain any un-amendable clauses might suggest that in Colombia the power of constitutional reform is not subject to any substantive limits. Nevertheless, the absence of eternity clauses, according to the Court, only meant that any provision of the Constitution of 1991 could be reformed and modified, not that one could use the amendment process to, instead of reforming the constitution, replacing it with a new and different one. ${ }^{43}$ When a constitution is reformed, even if a referendum is required by the amendment rule, what takes place is an exercised of constituted power, which is by definition regulated by the constitution and subject to any relevant explicit or implicit limits. ${ }^{44}$

Nowhere in the amendment rule, it was stated, is there an authorisation "to eliminate or substitute the existing Constitution with a different one, something that can only be done by the constituent power". ${ }^{45}$ The Court limited itself to give one example of a "constitutional substitution":46

[f]or instance, the power of constitutional reform cannot be used in order to substitute the Social and Democratic State and the Republican form of government (Article 1) with a totalitarian state, a dictatorship or a monarchy, because that would mean that the Constitution of 1991 has been replaced with a new one.

Although in 2003 the Court upheld most of the amendments at issue, it has since then exercised its power to review the constitutionality of constitutional amendments in several cases (the most notable being a 2010 case in which the court invalidated an amendment that would have allowed President Alvaro Uribe to run for a third consecutive Presidential term). ${ }^{47}$

41 At [29].The Court cited with approval its Sentencia C-544/92.

42 At [29].

43 At [33].

44 This point was stressed in the more recent Sentencia C-141/10.

45 Setencia 551/03, above n 30, at [33].

46 At [33].

47 Sentencia C-141/10. 


\section{BEYOND PARLIAMENTARY SOVEREIGNTY AND JUDICIAL SUPREMACY}

A possible objection to the approach adopted by the Colombian Constitutional Court (as well as to the basic structure doctrine and common law constitutionalism) is that it could have the effect of making the constitutional regime legally permanent, thus indirectly promoting a constitutional rupture, a break in legal continuity, if the society determines that the substitution of the constitution (or the abandonment or replacement of certain fundamental principles) is necessary. ${ }^{48}$ In the 2003 case examined above, the Colombian Court considered that objection, and its response illustrates what distinguishes the Latin American version of the doctrine of implicit limits from other approaches that seek to limit constitutional change. The problem can be rephrased as follows: if a judiciary asserts its jurisdiction to declare certain amendments unconstitutional, and the Constitution does not provide any means for the exercise of constituent power, one arrives at the following dilemma: either the constituent power is asphyxiated by the limits to the power of constitutional reform, or a revolution is necessary in order to allow for an exercise of constituent power to take place.

In the opinion of the Court, the framers of the Constitution of 1991 attempted to 'solve' that problem, to ease the tension between popular sovereignty and constitutional supremacy, by providing an opening for constituent power to manifest through the institution of the Constituent Assembly (a mechanism that is absent from the constitutions of India and Belize, in which constitutional changes must be adopted by Parliament, in most cases by qualified majorities) ${ }^{49}$ The Constituent Assembly (which according to art 376 of the Constitution can only be convened through a referendum called by the legislature) could be used in those instances in which it becomes necessary to adopt a new constitution. ${ }^{50}$

It is true, expressed the Court, that a Constituent Assembly, as any mechanism that attempts to channel constituent power, is always imperfect, because by its very nature constituent power "does not admit a total institutionalisation". ${ }^{51}$ However, the Court continued, by providing the possibility

48 Sentencia 551/03, above n 30, at [40].

49 See art 69 of the Constitution of Belize (1981) and art 368 of the Constitution of India (1949). In 2008, the Turkish Constitutional Court declared invalid a set of amendments (which sought to abolish the headscarf ban in universities), using reasoning similar to that of the Colombian Constitutional Court in Sentencia 551/03. However, the Constitution of Turkey does not contain an opening for the exercise of constituent power (see art 175 of the Constitution of the Republic of Turkey (1982)). For a discussion of the Turkish decision, see Yaniv Roznai and Serkan Yolcu "An Unconstitutional Constitutional Amendment - The Turkish Perspective: A Comment on the Turkish Constitutional Court's Headscarf Decision" (2012) 10 ICON 175.

50 The Constitution of 1991 was adopted by a Constituent Assembly in violation of the amendment rule of the Constitution of 1886 .

51 Sentencia 551/03, above n 30, at [40]. 
to convene a Constituent Assembly, the constitution sought to facilitate, rather than to negate, the expression of constituent power without causing unnecessary legal ruptures. As we will see below, some new Latin American constitutions have attempted to democratize the institution of the Constituent Assembly by making it more participatory (allowing it to be convened by popular initiative), and have thus provided the electorate, acting outside the ordinary institutions of government, with the means of going beyond a judicial invalidation of a constitutional amendment.

Since being adopted by the Constitutional Court of Colombia, the doctrine of implicit limits has migrated to countries such as Venezuela, ${ }^{52}$ Peru, ${ }^{53}$ and Costa Rica. ${ }^{54}$ Moreover, it has been implicitly incorporated into the new constitutions of Bolivia (2009) and Ecuador (2008). ${ }^{55}$ For example, these new constitutions establish that constitutional amendments that touch on the constitution's "fundamental principles, its recognized rights, duties, and guarantees, or the supremacy of the constitution and the process of constitutional reform" 56 or that "set constraints on rights and guarantees...[or] change the procedure for amending the Constitution"57, must take place thorough a Constituent Assembly. Similar to art 376 of the Colombian Constitution, this Assembly would be convened through popular referendum.

However, in the case of Bolivia and Ecuador the referendum can be triggered by popular initiative (through the collection of the signatures of 20 per cent or 12 per cent of the registered electors, respectively). ${ }^{58}$ Once convened, the Assembly would draft a new constitution (or a radically transformed one) that would only become valid after being directly approved by the electorate in an additional referendum. This approach not only provides an opening for constituent power to manifest from time to time, but also gives citizens the legal means of initiating constituent episodes. In a way, this approach can be described as an attempt to leave the door open for future revolutionary episodes of constitutional change, similar to the ones that arguably took place when these constitutions were originally adopted.

52 See Opinion No 53 Supreme Court of Justice of Venezuela (Constitutional Chamber), 3 February 2009.

53 See Sentencia 050-2004-AI/TC Constitutional Court of Peru.

54 See Res 2010-13313 Supreme Court of Justice of Costa Rica (Constitutional Chamber),

55 These constitutions were also influenced by arts 347 and 348 of the Venezuelan Constitution of 1999, which allows the electorate, acting through popular initiative, to convene a Constituent Assembly for the transformation of the state, the creation of a new juridical order, and the drafting of a new Constitution. Before the adoption of the 2009 constitution, the doctrine of implicit limits was rejected by the Bolivian Tribunal Constitucional Plurinacional in 2004. See Expediente 2004-09014-19-RDI.

56 Constitution of Bolivia, art 411.

57 Constitution of Ecuador, arts 441-444.

58 Articles 411 and 444 of the Constitutions of Bolivia and Ecuador. 
Accordingly, these constitutions create a constitutional system in which, even though the legislature retains the ordinary power of constitutional reform and courts retain the power to declare amendments unconstitutional if they find them to be inconsistent with certain principles (as well as the ordinary power of judicial review of legislation), neither parliament nor the courts is given the final word on the validity of fundamental constitutional changes. That ultimate power is placed in the citizenry, not only at a level of constitutional discourse, but through the institutionalization of a mechanism that allows extra-parliamentary exercises of popular political power. This is why the Latin American version of the doctrine of implicit limits to the power of constitutional reform, although sharing important similarities with the doctrine of the basic structure and with common law constitutionalism, represents a different approach. Those two other doctrines developed in systems in which the struggle has always been between Parliament and the courts, and in which the people rarely make any appearances other than in regular elections. ${ }^{59}$

Instead of taking power away from a sovereign Parliament and placing it in the courts, the Latin American approach provides courts with the ability to limit Parliament's constitution-amending power without making judicial decisions final. Judicial declarations of invalidity would always be susceptible to being overridden by the people, who retain an unlimited power of constitutional change that must be exercised outside Parliament. This does not mean that judicial decisions about the validity of constitutional amendments are seen as something negative: on the contrary, judges are attributed with the responsibility of protecting the fundamentals of the constitutional order from Parliament. It is an open question whether the Latin American version of the doctrine of implicit limits will be able to live up to its twin goals: the constitutionalist promise of limiting the political power of the ordinary institutions of government, and the democratic promise of providing the people with the means of exercising their sovereignty independently of the state.

59 For an elaboration of this point in the context of referendums, see Stephen Tierney "Whose Political Constitution? Citizens and Referendums" (2013) GLJ (forthcoming). 